\title{
Morphometric parameters of plants of Crambe spp. during vegetation
}

\author{
Olena Vergun*, Oksana Shymanska, Dzhamal Rakhmetov, \\ Oleksandr Bondarchuk, Svitlana Rakhmetova
}

M.M. Gryshko National Botanical Garden of Ukraine, National Academy of Sciences, Kyiv, Ukraine

ORCID

Olena Vergun: https://orcid.org/0000-0003-2924-1580

Oksana Shymanska: https://orcid.org/0000-0001-8482-5883

Dzhamal Rakhmetov: https://orcid.org/0000-0001-7260-3263

Oleksandr Bondarchuk: https://orcid.org/0000-0001-6367-9063

Svitlana Rakhmetova: https://orcid.org/0000-0002-0357-2106

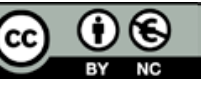

Article Details:

Received: 2021-07-08

Accepted: 2021-08-03

Available online: 2021-11-30

DOI: https://doi.org/10.15414/ainhlq.2021.0022

Plants of Crambe spp. belong to Brassicaceae Burnett family and some of them are known as economically important species. Extracts of Crambe spp. exhibited numerous biological activities such as antioxidant, antimicrobial, antiproliferative, cytotoxic, etc. This study was aimed to research morphometric parameters of plants of five species of Crambe L. during vegetation season (from the start of vegetation, budding stage, flowering stage, and to fruitage): C. cordifolia Steven, C. hispanica subsp. abyssinica (Hochst. et R.E.Fr.) Prina, C. koktebelica (Junge) N. Busch, C. maritima L., C. steveniana Rupr. The plant height, leaf length, leaf width, petiole length, length of panicle measured in $\mathrm{cm}$, flower length, flower width, corolla length, petal length, petal width, fruit length, and fruit diameter measured in mm. The increment of investigated plants at the period of vegetation start-budding was 47.7-128.9 cm and plant height increased 2.67 (C. maritima) - 5.57 (C. koktebelica) times, at the budding-flowering period 9.7-94.4 cm and plant height increased 1.08 (C. cordifolia) - 1.85 (C. steveniana) times, at the period flowering-fruiting $8.20-26.0 \mathrm{~cm}$ and plant height increased 1.06 (C. cordifolia) - 1.10 (C. maritima) times. The variability of morphometric features during vegetation was following: height of plant from 0.57 to $13.98 \%$, length of leaf from 1.25 to $13.65 \%$, width of leaf from 2.17 to $48.10 \%$, length of petiole from 3.34 to $18.01 \%$, length of panicle from 1.41 to $13.09 \%$, width of panicle from 1.62 to $17.37 \%$, and stem diameter from 2.89 to $23.47 \%$. The study of morphometric parameters of flowers showed that the length of flower was 5.03-16.46 mm, width of flower 2.01-5.54 mm, corolla length 2.94-10.58 mm, petal length 3.63-7.11 mm, and petal width 3.64-5.51 mm depending on species. The morphometric parameters of fruits were the following: fruit length $3.02-10.10 \mathrm{~mm}$ and fruit diameter $4.08-8.78 \mathrm{~mm}$ depending on species. The thousand-fruit weight was 7.30-12.50 g. Selected morphometric parameters showed Pearson's coefficients with high values ( $\mathrm{r}=0.843-0.994)$ during vegetation. A comparative study of the morphometric parameters of investigated species of Crambe in M.M. Gryshko National Botanical Garden had a variability of morphometric parameters depending on species, period of growth, and organ of a plant. These results can be useful for selective work and detecting the diagnostic signs.

Keywords: Crambe, morphometric parameters, correlation

\footnotetext{
*Corresponding Author: Olena Vergun, M.M. Gryshko National Botanical Garden of Ukraine of National Academy of Sciences, Kyiv, Timiryazevska 1, 01014 Kyiv, Ukraine

$\triangle$ en vergun@ukr.net
} 


\section{Introduction}

Plants of the Crambe L. genus belong to Brassicaceae Burnett family and contain around 40 species (Francisco-Ortega et al., 2002; Prina, 2021). Some species from this genus are promising fodder, food, decorative and medicinal plants (Kalista, 2017). Plant raw is a rich source of nutrients (Vergun et al., 2018), especially ascorbic acid (Vergun et al., 2019). HPLC analysis of amino acid composition detected that Crambe cordifolia Steven and C. koktebelica (Junge) N.Busch contain the L-glutamic acid, glycine, L-arginine, L-leucine, which were predominant for both species (Slobodianiuk et al., 2021). Plant extracts of Crambe spp. exhibited cytotoxic, antiproliferative, allelopathic (Razavi and Nejad-Ebrahimi, 2009), antioxidant, and antimicrobial activities (Vergun et al., 2021). The essential oil of the leaves and flowering tops of $\mathrm{C}$. orientalis includes nitriles, isothiocyanates, esters, fatty acids, alkanes, ketones, aldehydes, terpenes. The major components in the flowering top oil were 2-methyl-5hexenenitrile and 3-butenyl isothiocyanate, in leaves octyl-acetate (Razavi and Nejad-Ebrahimi, 2009). The most well-known and economically important species among others is $C$. hispanica subsp. abyssinica (Hochst. et R.E.Fr.) that produces valuable vegetable oil with an erucic acid content of up to $50 \%$ (Queiroz et al., 2019; Samarappuli et al., 2020). Through genetic engineering and cross, breeding was obtained transgenic crambe lines producing wax esters that are important industrial feedstock (Li et al., 2019). This species is used as an alternative renewable energy source for biodiesel production (Kurt et al., 2018).

The study of shoot's system of different species showed that these plants are chamaephytes (Sanyal and Decocq, 2015) or hemicryptophytes (Scherbakova and Kalistaya, 2013; Sanyal and Decocq, 2015). C. abissinica and C. maritima can grow on saline soils and be tolerant to salty water irrigation (Vos et al., 2010; Qi et al., 2017).

Considering the important value of these plants and the lack of information this work was aimed to study some morphometric peculiarities of five Crambe species growing in the Forest-Steppe of Ukraine. The study of morphometric parameters of plants is a very important aspect due to origin, condition of growth, especially concerning introduction in a new area, peculiarities of vegetative reproduction (Buckley et al., 1997; Brindza et al., 2019). The research of morphometric parameters is also valuable for the ecological estimation of plants (Meng et al., 2009).

\section{Material and methodology}

\section{Biological material}

In this study investigated species from Crambe L.: C. cordifolia Steven, C. hispanica subsp. abyssinica (Hochst. et R.E.Fr.) Prina, C. koktebelica (Junge) N. Busch, C. maritima L., C. steveniana Rupr. The plants were studied in 2018-2019 at the experimental fields of the M.M. Gryshko National Botanical Garden of the NAS of Ukraine in the Kyiv city (50²4' $55^{\prime \prime}$ N, 30 $33^{\prime} 45^{\prime \prime}$ E) during vegetation season. Photos of flowers taken with digital USB microscope Sigeta Expert.

\section{Morphometric characteristics}

Morphometric parameters fixed at the start of vegetation, budding, flowering, and fruitage. The measuring of plant height, length, and width of leaves, length of petioles, length of panicles were used. The length and width of flower, corolla length, length, and width of petal were used as morphometric parameters of flowers. The fruit length and diameter of fruits were used to measure the fruits. Thousand-fruit mass weighed on analytical scales Kern ACJ.

\section{Statistical analysis}

Data were analysed with the ANOVA test and differences between means compared through the Tukey-Kramer test $(\mathrm{p}<0.05)$. The variability of all these parameters was evaluated using descriptive statistics.

\section{Results and discussion}

The study of morphological, morphometric, physiological, etc., characteristics of plants due to climate change is becoming a global last time. The temperature fluctuations influence duration of the vegetation period and biomorphological peculiarities of plants (Aslam et al., 2021). The leaf is one of the most significant features for the identification of concrete species in plant morphology among other plant organs. Wherein have used different classifications of leaf features (Kumar et al., 2019). The morphometric parameters of leaves can be useful in ecophysiological study to estimate the tolerance of a plant to the environment, for example, in the case of $C$. maritima as a salt-tolerant crop (Vos et al., 2010).

Investigated plants of Crambe belong to the perennial (C. cordifolia, C. koktebelica, C. maritima, C. steveniana) and annual ( $C$. hispanica subsp. abyssinica) plants. They originate from the Mediterranean and East African regions, species distributed from Macronesian archipelagoes to the West of China and from the 

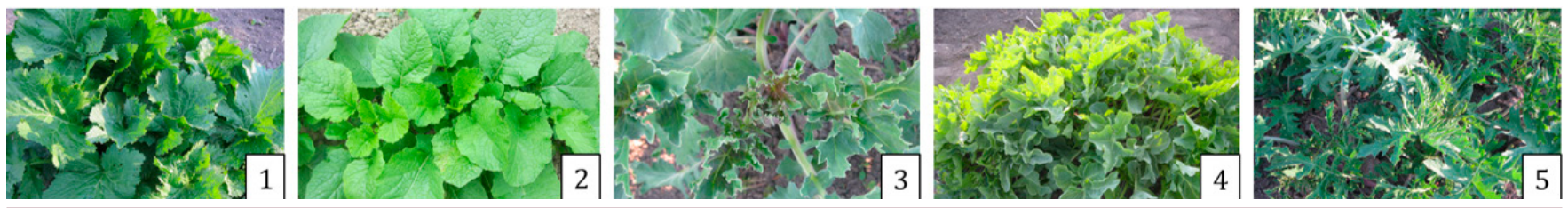

Figure 1 Plants of Grambe L. genus at the start of vegetation

1 - C. hispanica subsp. abyssinica (Hochst. et R.E.Fr.) Prina; 2 - C. cordifolia Steven; 3 - C. koktebelica (Junge) N. Busch; 4 - C. maritima L.; 5 - C. steveniana Rupr.

Arctic Polar Circle to the Scandinavian Peninsula, etc. (Prina, 2009). In conditions of the Ukrainian ForestSteppe, these plants pass a full cycle of growth and development. The duration of vegetation period for C. cordifolia, C. koktebelica, C. maritima, C. steveniana was $122,121,98$, and 124 days, respectively. We observed that the average start of vegetation for all perennial plants was on $13^{\text {th }}$ March- $2^{\text {nd }}$ April, budding started on $27^{\text {th }}$ April-14 ${ }^{\text {th }}$ May, flowering started on $10^{\text {th }}$ May- $7^{\text {th }}$ June, and fruiting on $3^{\text {rd }}$ June $-12^{\text {th }}$ July. The start of growth at the beginning of vegetation depending on climate conditions of years that was also noticed in the study Fontana et al. (1998).

At the start of vegetation (spring growing), beginning from the second year, plants formed the rosette of leaves (Figure 1) after that formed following vegetativegenerative plant shoots. This period continues to average 44-62 days.

We measured morphometric parameters during vegetation period, and plant height at the start of vegetation was from 15.00 to $28.40 \mathrm{~cm}$ (Table 1).
Leaf length and width in this period were 9.00-20.20 $\mathrm{cm}$ and 5.03-15.36 cm, respectively. The length of petioles was from 2.96 to $16.37 \mathrm{~cm}$. The variability of morphometric parameters (V \%) at the period of start vegetation was following: plant height 2.71-13.98 \%, leaf length 3.71-13.65 \%, leaf width 2.55-11.44\%, length of petiole $4.88-11.94 \%$. The level of variability of plant morphometric parameters is often studied in the context of weather conditions such as a sum of effective temperatures, precipitations (Mikolaychuk, 2007), and changing of growth conditions (Gorlacheva and Kustova, 2013). The study of selected morphobiometric parameters of plants is important to research differences between genotypes (Bella et al., 2020).

At the budding stage height of plants was from 63.80 to $157.10 \mathrm{~cm}$, leaf length from 18.13 to $64.60 \mathrm{~cm}$, leaf width from 7.13 to $39.00 \mathrm{~cm}$, length of petiole from 8.31 to $30.10 \mathrm{~cm}$, and length of panicles from 18.00 to $147.80 \mathrm{~cm}$ depending on species (Table 2). The increment of investigated plants was $47.7-128.9 \mathrm{~cm}$ and plant height increased 2.67 (C. maritima) -5.57

Table 1 Morphometric parameters of plants of Crambe spp. at the start of vegetation

\begin{tabular}{lcccc}
\hline Species & Height of plant (cm) & Leaf length (cm) & Leaf width (cm) & Length of petiole (cm) \\
\hline C. cordifolia & $27.80 \pm 0.24^{\mathrm{a}}$ & $17.62 \pm 0.21^{\mathrm{a}}$ & $15.36 \pm 0.13^{\mathrm{a}}$ & $16.37 \pm 0.28^{\mathrm{a}}$ \\
C. hispanica subsp. abyssinica & $15.00 \pm 0.67^{\mathrm{c}}$ & $11.29 \pm 0.49^{\mathrm{c}}$ & $5.03 \pm 0.18^{\mathrm{c}}$ & $2.96 \pm 0.08^{\mathrm{d}}$ \\
C. koktebelica & $28.20 \pm 0.65^{\mathrm{a}}$ & $13.25 \pm 0.20^{\mathrm{b}}$ & $9.17 \pm 0.08^{\mathrm{b}}$ & $6.35 \pm 0.10^{\mathrm{b}}$ \\
C. maritima & $28.40 \pm 1.11^{\mathrm{a}}$ & $9.00 \pm 0.30^{\mathrm{d}}$ & $6.80 \pm 0.20^{\mathrm{c}}$ & $4.54 \pm 0.17^{\mathrm{c}}$ \\
C. steveniana & $25.00 \pm 0.30^{\mathrm{b}}$ & $20.20 \pm 0.25^{\mathrm{a}}$ & $12.35 \pm 0.15^{\mathrm{a}}$ & $8.88 \pm 0.16^{\mathrm{b}}$ \\
\hline
\end{tabular}

Notes: different superscripts in each column indicate the significant differences in the mean at $\mathrm{p}<0.05$

Table 2 Morphometric parameters of plants of Crambe spp. at the budding stage

\begin{tabular}{|c|c|c|c|c|c|}
\hline Species & $\begin{array}{l}\text { Height of plant } \\
(\mathrm{cm})\end{array}$ & $\begin{array}{c}\text { Leaf length } \\
\text { (cm) }\end{array}$ & Leaf width $(\mathrm{cm})$ & $\begin{array}{c}\text { Length of } \\
\text { petiole }(\mathrm{cm})\end{array}$ & $\begin{array}{c}\text { Length of } \\
\text { panicle }(\mathrm{cm})\end{array}$ \\
\hline C. cordifolia & $116.00 \pm 1.01^{\mathrm{b}}$ & $37.80 \pm 0.64^{\mathrm{b}}$ & $39.00 \pm 0.78^{\mathrm{a}}$ & $29.90 \pm 0.82^{\mathrm{a}}$ & $75.60 \pm 0.74^{\mathrm{b}}$ \\
\hline C. hispanica subsp. abyssinica & $63.80 \pm 1.72^{\mathrm{c}}$ & $18.13 \pm 0.29^{c}$ & $7.13 \pm 0.13^{c}$ & $8.31 \pm 0.20^{c}$ & $18.00 \pm 0.75$ \\
\hline C. koktebelica & $157.10 \pm 1.24^{\mathrm{a}}$ & $64.60 \pm 1.18^{a}$ & $26.60 \pm 0.74^{\mathrm{b}}$ & $13.80 \pm 0.36^{b}$ & $147.80 \pm 2.00^{\mathrm{a}}$ \\
\hline C. maritima & $76.10 \pm 1.22^{\mathrm{c}}$ & $29.50 \pm 0.76^{\mathrm{b}}$ & $25.60 \pm 1.53^{\mathrm{b}}$ & $16.60 \pm 0.95^{\mathrm{b}}$ & $66.10 \pm 0.70^{\mathrm{b}}$ \\
\hline C. steveniana & $80.60 \pm 2.56^{c}$ & $35.00 \pm 0.80^{\mathrm{b}}$ & $27.00 \pm 0.78^{\mathrm{b}}$ & $30.10 \pm 1.43^{\mathrm{a}}$ & $79.70 \pm 0.58^{\mathrm{b}}$ \\
\hline
\end{tabular}

Notes: different superscripts in each column indicate the significant differences in the mean at $\mathrm{p}<0.05$ 


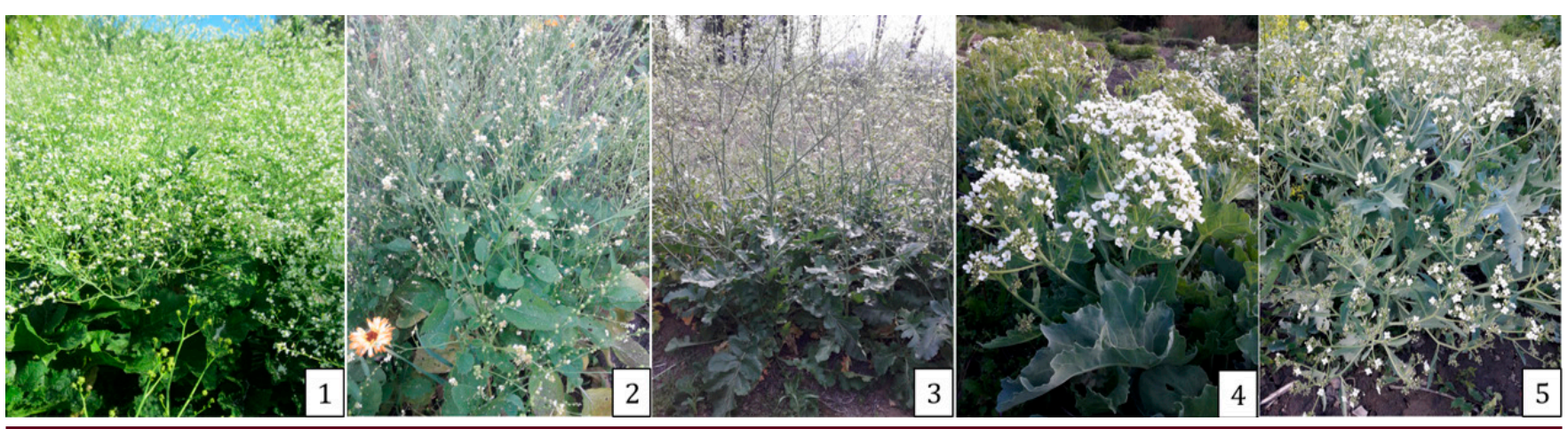

Figure 2 Plants of Grambe L. at the flowering stage

1 - C. cordifolia Steven; 2 - C. hispanica subsp. abyssinica (Hochst. et R.E.Fr.) Prina; 3 - C. koktebelica (Junge) N. Busch; 4 - C. maritima L.; 5 - C. steveniana Rupr.

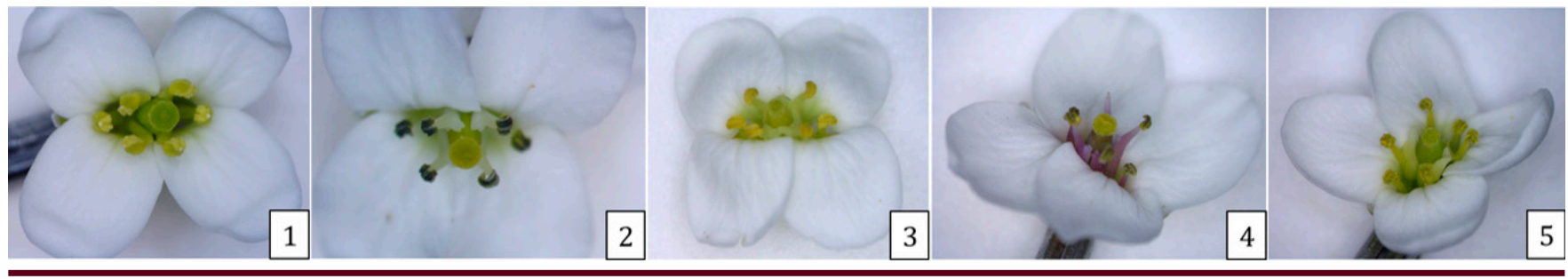

Figure 3 Flowers of plants of Grambe L.

1 - C. cordifolia Steven; 2 - C. hispanica subsp. abyssinica (Hochst. et R.E.Fr.) Prina; 3 - C. koktebelica (Junge) N. Busch; 4 - C. maritima L.; 5 - C. steveniana Rupr.

(C. koktebelica) times. At the budding stage, the variability of morphometric parameters was 2.46-9.95 $\%$ for plant height, 5.04-8.03 \% for leaf length, 5.53-18.71\% for leaf width, $7.70-18.01 \%$ for length of petiole, $2.29-13.09 \%$ for panicle length, 3.25-17.37 \% for panicle width, and $6.02-23.47 \%$ for stem diameter.

At the flowering stage (Figure 2) length of plants was from 73.50 to $251.50 \mathrm{~cm}$, leaf length from 21.60 to $86.90 \mathrm{~cm}$, leaf width from 8.22 to $68.10 \mathrm{~cm}$, length of petioles from 10.55 to $42.70 \mathrm{~cm}$, and length of panicles from 25.60 to $160.90 \mathrm{~cm}$ depending on species (Table 3).

The height of plants of $C$. hispanica subsp. abyssinica was 51.9-90.7 cm, according to Kurt et al. (2018). The increment of studied plants at the budding-flowering period was 9.7-94.4 $\mathrm{cm}$ and plant height increased 1.08 (C. cordifolia)-1.85 (C. steveniana) times. The variability of morphometric parameters at the period of flowering was following: plant height $1.90-3.64 \%$, leaf length $2.81-10.28 \%$, leaf width $2.28-48.10 \%$, length of petiole 5.91-9.89\%, length of panicles 2.77-9.24\%, width of panicle $2.46-6.78 \%$, and $6.21-9.90 \%$.

Flowers of Crambe spp. are typical for Brassicaceae and consist of 4 petals, 6 stamens (Figure 3) and collected in the panicles.

Flower elements had the following values depending on species: flower length was 5.03-16.46 mm, flower width was $0.23-0.55 \mathrm{~mm}$, corolla length was 2.94-7.14 mm, petal length 3.63-6.56 mm, petal width 3.64-5.51 mm (Table 4).

Table 3 Morphometric parameters of plants of Crambe spp. at the flowering

\begin{tabular}{lccccc}
\hline Species & $\begin{array}{c}\text { Height of plant } \\
\text { (cm) }\end{array}$ & $\begin{array}{c}\text { Leaf length } \\
\text { (cm) }\end{array}$ & $\begin{array}{c}\text { Leaf width } \\
\text { (cm) }\end{array}$ & $\begin{array}{c}\text { Length } \\
\text { of petiole }(\mathbf{c m})\end{array}$ & $\begin{array}{c}\text { Length } \\
\text { of panicle }(\mathbf{c m})\end{array}$ \\
\hline C. cordifolia & $126.30 \pm 0.77 \mathrm{~b}$ & $43.80 \pm 0.84 \mathrm{~b}$ & $42.30 \pm 0.60 \mathrm{~b}$ & $38.30 \pm 0.72 \mathrm{a}$ & $84.80 \pm 0.75 \mathrm{~b}$ \\
C. hispanica subsp. abyssinica & $73.50 \pm 0.86 \mathrm{c}$ & $21.60 \pm 0.71 \mathrm{c}$ & $8.22 \pm 0.06 \mathrm{c}$ & $10.55 \pm 0.20 \mathrm{c}$ & $25.60 \pm 0.76 \mathrm{c}$ \\
C. koktebelica & $251.50 \pm 2.84 \mathrm{a}$ & $67.60 \pm 0.61 \mathrm{a}$ & $29.80 \pm 0.36 \mathrm{~b}$ & $21.20 \pm 0.67 \mathrm{~b}$ & $160.90 \pm 1.97 \mathrm{a}$ \\
C. maritima & $95.10 \pm 0.83 \mathrm{c}$ & $48.00 \pm 0.90 \mathrm{~b}$ & $35.701 .20 \mathrm{~b}$ & $28.80 \pm 0.62 \mathrm{~b}$ & $79.90 \pm 1.16 \mathrm{~b}$ \\
C. steveniana & $149.60 \pm 1.78 \mathrm{~b}$ & $86.90 \pm 0.99 \mathrm{a}$ & $68.10 \pm 1.20 \mathrm{a}$ & $42.70 \pm 0.84 \mathrm{a}$ & $92.20 \pm 0.85 \mathrm{~b}$ \\
\hline
\end{tabular}

Notes: different superscripts in each column indicate the significant differences in the mean at $\mathrm{p}<0.05$ 
At the fruiting stage length of plants was from 78.50 to $277.90 \mathrm{~cm}$, leaf length from 25.60 to $96.10 \mathrm{~cm}$, leaf width from 10.50 to $77.80 \mathrm{~cm}$, length of petioles from 12.50 to $53.20 \mathrm{~cm}$, and length of panicles from 33.80 to $186.50 \mathrm{~cm}$ (Table 5). At the period flowering-fruiting increment of investigated plants was $8.20-26.0 \mathrm{~cm}$. According to Rakhmetov and Rakhmetova (2015), the increment of different genotypes of Brassica rapa L. $\times$ B. campestris $\mathrm{f}$. biennis DC. at the period of floweringripening was in the range $10.1-20.6 \mathrm{~cm}$. The variability of investigated parameters was $0.57-4.04 \%$ for plant height, $1.25-6.39 \%$ for leaf length, $2.17-6.73 \%$ for leaf width, 3.34-6.37\% for length of petiole, 1.41-6.80\% for length of flowering, 1.62-4.93\% for the width of panicle, $2.89-8.00 \%$ for stem diameter.

According to faceted classification, developed by Iljinska (2013), fruits of the Crambe genus are related to choriarticulate-pseudoseptate dimericarps. Crambe fruits consist of two segments, where the only top seedcontaining segment is fully developed (Kalista et al., 2014).
Fruit length in our study was $3.02-10.10 \mathrm{~mm}$, diameter 3.41-8.78 mm (Table 6). One of the most important characteristics of fruits and seeds is the thousand-fruit weight. That is a significant parameter, among others, of seed and oil yield (Kwiatkowski et al., 2020). Thousandfruit weight in our study was 7.30-12.50 g. Kwiatkowski et al. (2020) determined this parameter for C. abyssinica as $7 \mathrm{~g}$ on average that was $1.5 \mathrm{~g}$ less than in our study.

The study of correlations between morphometric parameters is widely used in botanical science for different plant parts such as fruits (Ivanišová etal., 2017; Grygorieva et al., 2018a; Mangino et al., 2021), leaves (Chitwood and Otoni, 2017; Grygorieva et al., 2018b), etc. Between studied morphometric parameters, we found a correlation with different levels. A very strong correlation was found between leaf width and petiole length $(r=0.959)$, leaf length and width $(r=0.844)$, a strong correlation was between leaf length and length of petiole $(r=0.708)$ at the start of vegetation period (Table 7).

Table 4 Morphometric parameters of Crambe spp. flowers

\begin{tabular}{lccccc}
\hline Species & $\begin{array}{c}\text { Flower length } \\
(\mathbf{m m})\end{array}$ & $\begin{array}{c}\text { Flower width } \\
(\mathbf{m m})\end{array}$ & $\begin{array}{c}\text { Corolla length } \\
(\mathbf{m m})\end{array}$ & $\begin{array}{c}\text { Petal length } \\
(\mathbf{m m})\end{array}$ & $\begin{array}{c}\text { Petal width } \\
(\mathbf{m m})\end{array}$ \\
\hline C. cordifolia & $14.91 \pm 0.21^{\mathrm{b}}$ & $4.52 \pm 0.01^{\mathrm{a}}$ & $6.35 \pm 0.05^{\mathrm{b}}$ & $5.61 \pm 0.08^{\mathrm{a}}$ & $4.54 \pm 0.08^{\mathrm{a}}$ \\
C. hispanica subsp. abyssinica & $12.04 \pm 0.18^{\mathrm{b}}$ & $2.01 \pm 0.06^{\mathrm{b}}$ & $10.58 \pm 0.07^{\mathrm{a}}$ & $7.11 \pm 0.26^{\mathrm{a}}$ & $4.22 \pm 0.14^{\mathrm{a}}$ \\
C. koktebelica & $5.03 \pm 0.09^{\mathrm{c}}$ & $2.32 \pm 0.01^{\mathrm{b}}$ & $2.94 \pm 0.07^{\mathrm{c}}$ & $3.63 \pm 0.04^{\mathrm{b}}$ & $3.64 \pm 0.07^{\mathrm{b}}$ \\
C. maritima & $16.14 \pm 0.72^{\mathrm{a}}$ & $4.27 \pm 0.04^{\mathrm{a}}$ & $6.23 \pm 0.21^{\mathrm{b}}$ & $5.49 \pm 0.24^{\mathrm{a}}$ & $4.71 \pm 0.10^{\mathrm{a}}$ \\
C. steveniana & $16.46 \pm 0.10^{\mathrm{a}}$ & $5.54 \pm 0.01^{\mathrm{a}}$ & $7.14 \pm 0.28^{\mathrm{b}}$ & $6.56 \pm 0.09^{\mathrm{a}}$ & $5.51 \pm 0.07^{\mathrm{a}}$ \\
\hline
\end{tabular}

Notes: different superscripts in each column indicate the significant differences in the mean at $\mathrm{p}<0.05$

Table 5 Morphometric parameters of plants of Crambe spp. at the fruiting

\begin{tabular}{lccccc}
\hline Species & $\begin{array}{c}\text { Height of plant } \\
(\mathbf{c m})\end{array}$ & $\begin{array}{c}\text { Leaf length } \\
(\mathbf{c m})\end{array}$ & Leaf width (cm) & $\begin{array}{c}\text { Length of } \\
\text { petiole }(\mathbf{c m})\end{array}$ & $\begin{array}{c}\text { Length of } \\
\text { panicle }(\mathbf{c m})\end{array}$ \\
\hline C. cordifolia & $134.70 \pm 0.48^{\mathrm{a}}$ & $53.70 \pm 1.10^{\mathrm{b}}$ & $47.20 \pm 0.42^{\mathrm{b}}$ & $44.70 \pm 0.48^{\mathrm{a}}$ & $94.70 \pm 0.71^{\mathrm{b}}$ \\
C. hispanica subsp. abyssinica & $78.50 \pm 1.01^{\mathrm{b}}$ & $25.60 \pm 0.50^{\mathrm{c}}$ & $10.50 \pm 0.23^{\mathrm{c}}$ & $12.50 \pm 0.23^{\mathrm{c}}$ & $33.80 \pm 0.73^{\mathrm{c}}$ \\
C. koktebelica & $277.90 \pm 0.51^{\mathrm{a}}$ & $76.70 \pm 0.71^{\mathrm{a}}$ & $37.30 \pm 0.48^{\mathrm{b}}$ & $25.00 \pm 0.40^{\mathrm{b}}$ & $186.50 \pm 0.84^{\mathrm{a}}$ \\
C. maritima & $104.40 \pm 0.80^{\mathrm{b}}$ & $53.70 \pm 0.58^{\mathrm{b}}$ & $43.80 \pm 0.47^{\mathrm{b}}$ & $36.30 \pm 0.74^{\mathrm{b}}$ & $87.80 \pm 0.56^{\mathrm{b}}$ \\
C. steveniana & $162.70 \pm 0.67^{\mathrm{a}}$ & $96.10 \pm 0.38^{\mathrm{a}}$ & $77.80 \pm 0.54^{\mathrm{a}}$ & $53.20 \pm 0.62^{\mathrm{a}}$ & $103.10 \pm 0.53^{\mathrm{b}}$ \\
\hline
\end{tabular}

Notes: different superscripts in each column indicate the significant differences in the mean at $\mathrm{p}<0.05$

Table 6 Morphometric parameters and mass of fruits of Crambe spp.

\begin{tabular}{lccc}
\hline Species & Fruit length (mm) & Fruit diameter $(\mathbf{m m})$ & Thousand-fruit weight $(\mathrm{g})$ \\
\hline C. cordifolia & $3.20 \pm 0.13^{\mathrm{b}}$ & $4.08 \pm 0.06^{\mathrm{b}}$ & $7.30 \pm 0.15^{\mathrm{b}}$ \\
C. hispanica subsp. abyssinica & $3.02 \pm 0.12^{\mathrm{b}}$ & $3.41 \pm 0.09^{\mathrm{c}}$ & $8.50 \pm 0.17^{\mathrm{b}}$ \\
C. koktebelica & $4.10 \pm 0.10^{\mathrm{b}}$ & $4.30 \pm 0.10^{\mathrm{b}}$ & $8.70 \pm 0.15^{\mathrm{b}}$ \\
C. maritima & $10.10 \pm 0.35^{\mathrm{a}}$ & $8.78 \pm 0.15^{\mathrm{a}}$ & $12.50 \pm 0.23^{\mathrm{a}}$ \\
C. steveniana & $5.30 \pm 0.22^{\mathrm{b}}$ & $5.58 \pm 0.16^{\mathrm{b}}$ & $11.10 \pm 0.18^{\mathrm{a}}$ \\
\hline
\end{tabular}

Notes: different superscripts in each column indicate the significant differences in the mean at $\mathrm{p}<0.05$ 
Table 7 Pearson's coefficients between morphometric parameters of Crambe spp. at the start of vegetation

\begin{tabular}{lcccc}
\hline Parameter & Height of plant & Length of leaf & Width of leaf & Length of petiole \\
\hline Length of leaf & 0.173 & 1 & & 1 \\
Width of leaf & $0.537^{*}$ & $0.843^{* *}$ & $0.959^{* *}$ & 1 \\
Length of petiole & 0.473 & $0.708^{*}$ & & 1 \\
\hline
\end{tabular}

Notes: ${ }^{* *}$ - correlation is significant at the level of $0.01 ;^{*}$ - correlation is significant at the level of 0.05

Table 8 Pearson's coefficients between morphometric parameters of Crambe spp. at the budding stage

\begin{tabular}{|c|c|c|c|c|c|}
\hline Parameter & Height of plant & Length of leaf & Width of leaf & Length of petiole & Length of panicle \\
\hline Length of leaf & $0.955^{* *}$ & 1 & & & \\
\hline Width of leaf & $0.524^{*}$ & 0.489 & 1 & & \\
\hline Length of petiole & 0.074 & 0.093 & $0.792^{*}$ & 1 & \\
\hline Length of panicle & $0.904^{* *}$ & $0.986^{* *}$ & $0.539 *$ & 0.162 & 1 \\
\hline
\end{tabular}

Notes: ${ }^{* *}$ - correlation is significant at the level of $0.01 ;{ }^{*}$ - correlation is significant at the level of 0.05

Table 9 Pearson's coefficients between morphometric parameters of Crambe spp. at the flowering stage

\begin{tabular}{|c|c|c|c|c|c|c|c|c|c|}
\hline Parameter & HP & LL & WL & LP & LPN & LF & WF & LC & LPT \\
\hline LL & $0.641^{*}$ & 1 & & & & & & & \\
\hline WL & 0.232 & $0.843^{* *}$ & 1 & & & & & & \\
\hline LP & 0.103 & $0.659^{*}$ & $0.945^{* *}$ & 1 & & & & & \\
\hline LPN & $0.953^{* *}$ & $0.676^{*}$ & 0.334 & 0.246 & 1 & & & & \\
\hline LF & $-0.731^{*}$ & -0.004 & 0.483 & 0.585 & -0.588 & 1 & & & \\
\hline WF & -0.144 & $0.566^{*}$ & $0.911^{* *}$ & $0.953^{* *}$ & 0.017 & $0.780^{*}$ & 1 & & \\
\hline LC & $-0.858^{* *}$ & -0.577 & -0.305 & -0.280 & $-0.968^{* *}$ & 0.495 & -0.067 & 1 & \\
\hline LPT & $-0.831^{* *}$ & -0.329 & 0.007 & 0.014 & $-0.910^{* *}$ & $0.685^{*}$ & 0.232 & $0.949^{* *}$ & 1 \\
\hline WP & -0.408 & 0.426 & $0.767^{*}$ & $0.733^{*}$ & -0.324 & $0.873^{* *}$ & $0.884^{* *}$ & 0.332 & $0.605^{*}$ \\
\hline
\end{tabular}

Notes: HP - height of plants; LL - length of leaf; WL - width of leaf; LP - length of petiole; LPN - length of panicles; LF - length of flower; WF - width of flower; LC - length of corolla; LPT - length of petal; WP - width of petal; ${ }^{* *}$ - correlation is significant at the level of $0.01 ;^{*}$ - correlation is significant at the level of 0.05

Table 10 Pearson's coefficients between morphometric parameters of Crambe spp. at the fruiting

\begin{tabular}{|c|c|c|c|c|c|c|c|}
\hline Parameter & HP & LL & WL & LP & LPN & FL & FD \\
\hline LL & $0.659^{*}$ & 1 & & & & & \\
\hline WL & 0.260 & $0.876^{* *}$ & 1 & & & & \\
\hline LP & 0.072 & $0.701^{*}$ & $0.947^{* *}$ & 1 & & & \\
\hline LPN & $0.970^{* *}$ & $0.673^{*}$ & 0.328 & 0.175 & 1 & & \\
\hline FL & -0.195 & 0.136 & 0.272 & 0.260 & 0.001 & 1 & \\
\hline FD & -0.195 & 0.196 & 0.363 & 0.365 & 0.008 & $0.994^{* *}$ & 1 \\
\hline TFW & -0.175 & 0.324 & 0.420 & 0.313 & -0051 & $0.905^{* *}$ & $0.901^{* *}$ \\
\hline
\end{tabular}

Notes: HP - height of plants; LL - length of leaf; WL - width of leaf; LP - length of petiole; LPN - length of panicles; FL - length of fruit; FD - fruit diameter; TFW - thousand-fruit weight; ${ }^{* *}$ - correlation is significant at the level of $0.01 ;^{*}-$ correlation is significant at the level of 0.05

A very strong correlation was determined between leaf length and petiole length $(r=0.986)$, plant height and leaf length $(r=0.955)$, the height of plant and panicle length $(r=0.905)$, and strong relation found between leaf width and petiole length $(r=0.792)$ at the budding period (Table 8).
At the flowering stage, a very strong correlation was detected between petiole length and plant height ( $r=0.954)$, length of petiole and width of flower $(r=0.953)$, length of corolla and length of petal $(r=0.949)$, petiole length and leaf width $(r=0.945)$, width of flower and width of petal $(r=0.884)$, and between width and length of the leaf $(r=0.843)$ (Table 9). 
At the fruiting period length of fruit strongly correlated with fruit diameter $(r=0.994)$, plant height and length of panicle $(r=0.970)$, plant height and petiole length $(r=0.969)$, leaf width and petiole length $(r=0.947)$, flower length and thousand-fruit weight $(r=0.905)$, length and width of leaf $(r=0.877)$, length of leaf and length of petiole $(r=0.701)$ (Table 10).

\section{Conclusion}

Thus, a study of the morphometric parameters of investigated species of Crambe genus in M.M. Gryshko National Botanical Garden can be useful for further biological investigations of these plants due to the previous partial lack of data. We found that the width of leaf for $C$. steveniana at the flowering was the most variable parameter and the plant height for C. koktebelica at the fruiting was the least variable one. Also, considering obtained data, the results can be used for selective work with plants of Crambe spp. In addition, assume that some results of our study may use for the determination of diagnostic signs.

\section{Conflicts of interest}

The authors declare no conflict of interest.

\section{Ethical Statement}

This article does not contain any studies that would require an ethical statement.

\section{Acknowledgments}

The publication was prepared with the active participation of researchers in International Network AgrobioNet.

\section{References}

Aslam, M.A., Ahmed, M., Hassan, F.-U., Afzal, O., Mehmood, M.Z., Qadir, G., Asif, M., Komal, S., \& Hussain, T. (2021). Impact of temperature fluctuations of plant morphological and physiological traits. Building Climate Resilience in Agriculture. Springer, Cham, p. 25-52.

https://doi.org/10.1007/978-3-030-79408-8 3

Bella, M.C., Niklas, A., Toscano, S., Picchi, V., Romano, Scalzo, R.L., \& Branca, F. (2020). Morphometric characteristics, polyphenols and ascorbic acid variation in Brassica oleraceae L. novel foods: sprouts, microgreens, baby leaves. Agronomy, 10, 782. https://doi.org/10.3390/agronomy10060782

Brindza, J., Grygorieva, O., Klymenko, S., Vergun, O., Mareček, J., \& Ivanišová, E. (2019). Variation of fruits morphometric parameters and bioactive compounds of Asimina triloba (L.) Dunal germplasm collection. Potravinarstvo Slovak Journal of Food Science, 13(1), p. 1-7. https://doi.org/10.5219/1019
Buckley, D.S., Zasada, J.C., Tappeiner, J.C., \& Stone, D.M. (1997). Plant morphological characteristics as a tool in monitoring response to silvicultural activities. Communicating the role of silvivulture in managing the national forests: Proceedingsof the National Silviculture Workshop, p. 37-41.

Chitwood, D.H., \& Otoni, W.C. (2017). Morphometric analysis of Passiflora leaves: the relationship between landmarks of the vasculature and elliptical Fourier descriptors of the blade. GigaScience, 6(1), 1-13. https://doi.org/10.1093/gigascience/giw008

Fontana, F., Lazzeri, L., Malaguti, L., \& Galletti, S. (1998). Agronomic characterization of some Crambe abyssinica genotypes in a locality of the Po Valley. European Journal of Agronomy, 9, 117-126.

https://doi.org/10.1016/S1161-0301(98)00037-9

Francisco-Ortega, J., Fuertes-Aguilar, J., Kim, S.-Ch., SantosGuerra, A., Crawford, D.J., \& Jansen, R.K. (2002). Phylogeny of the Macaronesian endemic Crambe section Dendrocrambe (Brassicaceae) based on internal transcribed spacer sequences of nuclear ribosomal RNA. American Journal of Botany, 89(12), 1984-1990. https://doi.org/10.3732/ajb.89.12.1984

Gorlacheva, Z.S., \& Kustova, O.K. (2013). Minlyvist morpholohichnyh oznak Salvia officinalis L. pry introdukcii [Variability of the morphological characteristics of Salvia officinalis L. under introduction]. Plant Introduction, 58(2), 63-68. [In Ukrainian] https://doi.org/10.5281/zenodo.1492826

Grygorieva, O., Klymenko, S., Vinogradova, Yu., Iljinska, A., Piórecki, N., \& Brindza, J. (2018b). Leaf characteristics as important morphometric discriminators for chestnut (Castanea sativa Mill.) genotypes. Agrobiodiversity for Improving Nutrition, Health and Life Quality, 2, 146-158. https://doi.org/10.15414/ agrobiodiversity.2018.2585-8246.146-158

Grygorieva, O.V., Klymenko, S.V., Teslyuk, M., M.G., \& Onyschuk, L.M. (2018a). Variability of morphological parameters and determination of volatile organic compounds of sweet chestnut (Castanea sativa Mill.) genotypes fruits. Plant Introduction, 78(2), 74-83. https://doi.org/10.5281/zenodo.2230370

Iljinska, A.P. (2013). Suchasnipidhody do klasyfikacii plodiv Brassicaceae (na prykladi vydiv flory Ukrajiny) [Modern approaches to classification of fruits of Brassicaceae; a case study of taxa occurring in Ukraine]. Ukrainian Botanical Journal, 70(4), 467-478. [In Ukrainian]

Ivanišová, E., Grygorieva, O., Abrahamová, V., Schubertova, Z., Terentjeva, M., \& Brindza, J. (2017). Characterization of morphological parameters and biological activity of jujube fruit (Ziziphus jujuba Mill.). Journal of Berry Research, 7(4), 249-260. https://doi.org/10.3233/JBR-170162

Kalista, M. (2017). Underutilized medicinal species of Crambe L. Agrobiodiversity for Improving Nutrition, Health and Life Quality, 1, 216-220. https://dx.doi.org/10.15414/ agrobiodiversity.2017.2585-8246.216-220 
Kalista, M.S., Scherbakova, O.F., \& Popovich, A.V. (2014). Morfologichni osoblyvosti plodiv Crambe koktebelica ta Crambe mitridatis (Brassicaceae) [Morphological peculiarities of Crambe koktebelica and Crambe mitridatis fruits (Brassicaceae)]. Ukrainian Botanical Journal, 72(2), 188-195. [In Ukrainian] https://doi.org/10.15407/ukrbotj71.02.188

Kumar, M., Gupta, S., Gao, X., \& Singh, A. (2019). Plant species recognition using morphological features and adaptive boosting methodology. IEEE Access, 7, 163912-163918. https://doi.org/10.1109/ACCESS.2019.2952176

Kurt, O., Özyilmaz, T., \& Göre, M. (2018). Determination of yield components of some crambe genotypes in the world crambe collection. Scientific Papers. Series A. Agronomy, 51(1), 304-309.

Kwiatkowski, J., Krzyżaniak, M., Załuski, D., Stolarski, M.J., \& Tworkowski, J. (2020). The physical properties of fruits and the physiological quality of seeds of selected crambe genotypes. Industrial Crops and Products, 145, 1-9. https://doi.org/10.1016/j.indcrop.2019.1119777

Li, X., Guan, R., Fan, J., \& Zhu, L.-H. (2019). Development of industrial oil crop Crambe abyssinica for wax ester production through metabolic engineering and cross breeding. Plant Cell Physiol., 60(6), 1274-1283. https://doi.org/10.1093/pcp/pcz053

Mangino, G., Vilanova, S., Plazas, M., Prohens, J., \& Gramazio, P. (2021). Fruit shape morphometric analysis and QTL detection in a set of eggplant introgression lines. Scientia Horticulturae, 282, 110006. https://doi.org/10.1016/j.scienta.2021.110

Meng, T.-T., Ni, J., \& Harrison, S.P. (2009). Plant morphometric traits and climate gradients in northern China: a metaanalysis using quadrat and flora data. Annals of Botany, 104, 1217-1229. https://doi.org/10.1093/aob/mcp230

Mikolaychuk, V.G. (2007). Minlyvist morphometrychnyh parametriv bulb Cyperus esculentus L. (Cyperaceae) v umovah introdukcii v Pivnichne Prychernomorya [Variability of morphometric parameters of Cyperus esculentus L. (Cyperaceae) tubers in conditions of introduction to Northern Black sea cost]. Plant Introduction, 35(3), 16-19.

https://doi.org/10.5281/zenodo.2564140

Prina, A.0. (2009). Taxonomic review of the genus Crambe sect. Crambe (Brassicaceae, Brassiceae). Anales del Jardin Botanico de Madrid, 66(1), 7-24. https://doi.org/10.3989/ajbm.2186

Qi, W., Tinnenbroek-Capel, I.E.M., Salentijn, E.M.J., Zhang, Zh., Huang, B., Cheng, J., Shao, H., Visser, R.G.F, Krens, F.A., \& Van Loo, E.N. (2018). Genetically engineering Crambe abyssinica - a potentially high-value oil crop for salt land improvement. Land Degrad. Dev., 29, 1096-1106. https://doi.org/10.1002/Idr.2847

Queiroz, I.R., Santos, A.R., Matins, E.R., Costa, A.S.V., Azevedo, A.M., \& Fernandes, L.A. (2019). Agronomic performance of Crambe (Crambe abissinica) in the function of fertilization with sewage sludge and ecogypsums.
International Journal of Development Research, 9(5), 27685-27691.

Rakhmetov, D.B., \& Rakhmetova, S.O. (2015). Pidsumky introdukcii ta selekcii tyfonu (Brassica rapa L. $\times$ B. campestris f. biennis DC.) u Natsionalnomu botanichnomu sadu imeni M.M. Gryshka NAN Ukrajiny [Summary of introduction and breeding of typhon (Brassica rapa L. $\times$ B. campestris f. biennis DC.) in M.M. Gryshko National Botanical Garden of the NAS of Ukraine]. Plant Introduction, 68(4), 18-30. [In Ukrainian] https://doi.org/10.5281/zenodo.2527182

Razavi, S.M., \& Nejad-Ebrahimi, S. (2009). Chemical composition, allelopathic and cytotoxic effects od essential oils of flowering tops and leaves of Crambe orientalis L. from Iran. Natural Product Research, 23(16), 1492-1498. https://doi.org/10.1080/14786410802611303

Samarappuli, D., Zanetti, F., Berzuini, S., \& Berti, M.T. (2020). Crambe (Crambe abyssinica Hochst.): a non-food oilseed crop with great potential: a review. Agronomy, 10(9), 1380. https://doi.org/10.3390/agronomy10091380

Sanyal, A., \& Decocq, G. (2015). Biological flora of the British Isles: Crambe maritima. Journal of Ecology, 103, 769788. https://doi.org/10.1111/1365-2745.12389

Scherbakova, O.F., \& Kalistaya, M.S. (2013). Polyvariant architectural model of Crambe koktebelica (Junge) N.Busch shoot system. Plant Phytomorphology, 3, 153160. [In Russian] https://10.5281/zenodo.162007

Slobodianiuk, L., Budniak, L., Marchyshyn, S., Skrynchuk, O., \& Kudria, V. (2021). HPLC analysis of amino acids content in Crambe cordifolia and Crambe koktebelica leaves. International Journal of Applied Pharmaceutics, 13(4), 111-116. https://dx.doi.org/10.22159/ijap.2021v13i4.41265

Vergun, O., Rakhmetov, D., Shymanska, O., Bondarchuk, O., Ivanišová, E., Kačaniová, M., Grygorieva, O., \& Brindza, J. (2021). Assessment of antioxidant and antimicrobial activities of Crambe spp. during vegetation. Acta Scientiarum Polonorum Technologia Alimentaria, 20(2), 197-211. https://dx.doi.org/10.17306/J.AFS.2021.0927

Vergun, O., Shymanska, O., Rakhmetov, D., Fishchenko, V., Bondarchuk, O., \& Rakhmetova, S. (2019). Accumulation of nutrients in the raw of Crambe L. species. Agrobiodiversity for Improving Nutrition, Health and Life Quality, 1, 323-332. https://doi.org/10.15414/ agrobiodiversity.2019.2585-8246.323-332

Vergun, O.M., Rakhmetov, D.B., Shymanska, O.V., \& Fishchenko, V.V. (2018). The accumulation of nutrients in underground parts of plants of the genus Crambe spp. Plant Introduction, 78(2), 3-11. https://doi,org/10.5281/zenodo.2228725

Vos, A,C., Broekman, R., Groot, M.P., \& Rozema, J. (2010). Ecophysiological response of Crambe maritima to airborne and soil-borne salinity. Annals of Botany, 105, 925-937. https://doi.org/10.1093/aob/mcq072 